\title{
The geomorphological and environmental context of the Grd-i Tle archaeological site
}

\author{
István Viczián* \\ * - Geographical Institute, Research Centre for Astronomy and Earth Sciences, Budapest. \\ Email: viczian.istvan@csfk.org
}

\begin{abstract}
The geology, geomorphology and hydrography of the area around Grd-i Tle played an important role in the choice of location and the subsequent development of the settlement. The exceptionally abundant Saruchawa Spring as well as the fertile plains and gentle slopes around it made the settlement an important one on the Rania Plain. Grd-i Tle is located on the alluvial plain of the Qashan and Saruchawa Streams, at the foot of the Makook Ridge where several alluvial fans cover the plain at the mountain front. The fertile toe area of the fans and the alluvial plains have long been irrigated by the water of the Saruchawa Spring through a system of canals. The geomorphological position of the spring allows the irrigation of large areas around the tell. The raw materials used in the construction of the 28-metre-high tell with a volume of 1,716,496 $\mathrm{m}^{3}$ were available from nearby sources in considerable quantities. The building material for mud bricks came from the streams' floodplain near the tell. The morphological and lithological examination of the stones from the site and its broader area indicates that the stones for construction were collected from the coarse sediment of the upper part of the alluvial fan nearby Grd-i Tle.
\end{abstract}

Keywords: Grd-i Tle, tell, Rania Plain, Zagros, Makook, geomorphology, archaeology, environment

Cite as Viczián, I. 2020: The geomorphological and environmental context of the Grd-i Tle archaeological site. Hungarian Assyriological Review 1: 137-145. https://doi.org/10.52093/hara-20200200010-000

(c) (i) $($ This is an open access article distributed under the terms of the Creative Commons Attribution License, which permits unrestricted use, distribution, and reproduction in any medium, provided the original author and source are credited.

\section{Introduction}

The geomorphological investigation of the Grd-i Tle tell settlement and its broader area began in the 2019 excavation season of the Grd-i Tle Expedition. The main goal of the research is to improve our understanding of the archaeological sites and their environmental context by reconstructing past human-environment interactions and site formation processes.

The studied 28-metre-high artificial mound is the largest tell on the Rania Plain and it was presumably one of the most important settlement in the region. Our general approach is to understand which geographical features made this place attractive for human settlement and how the settlement prospered for millennia.

This paper presents the first results of the environmental reconstruction. Following a brief overview of the area's geological and hydrographic conditions and its landforms, we focus on two 


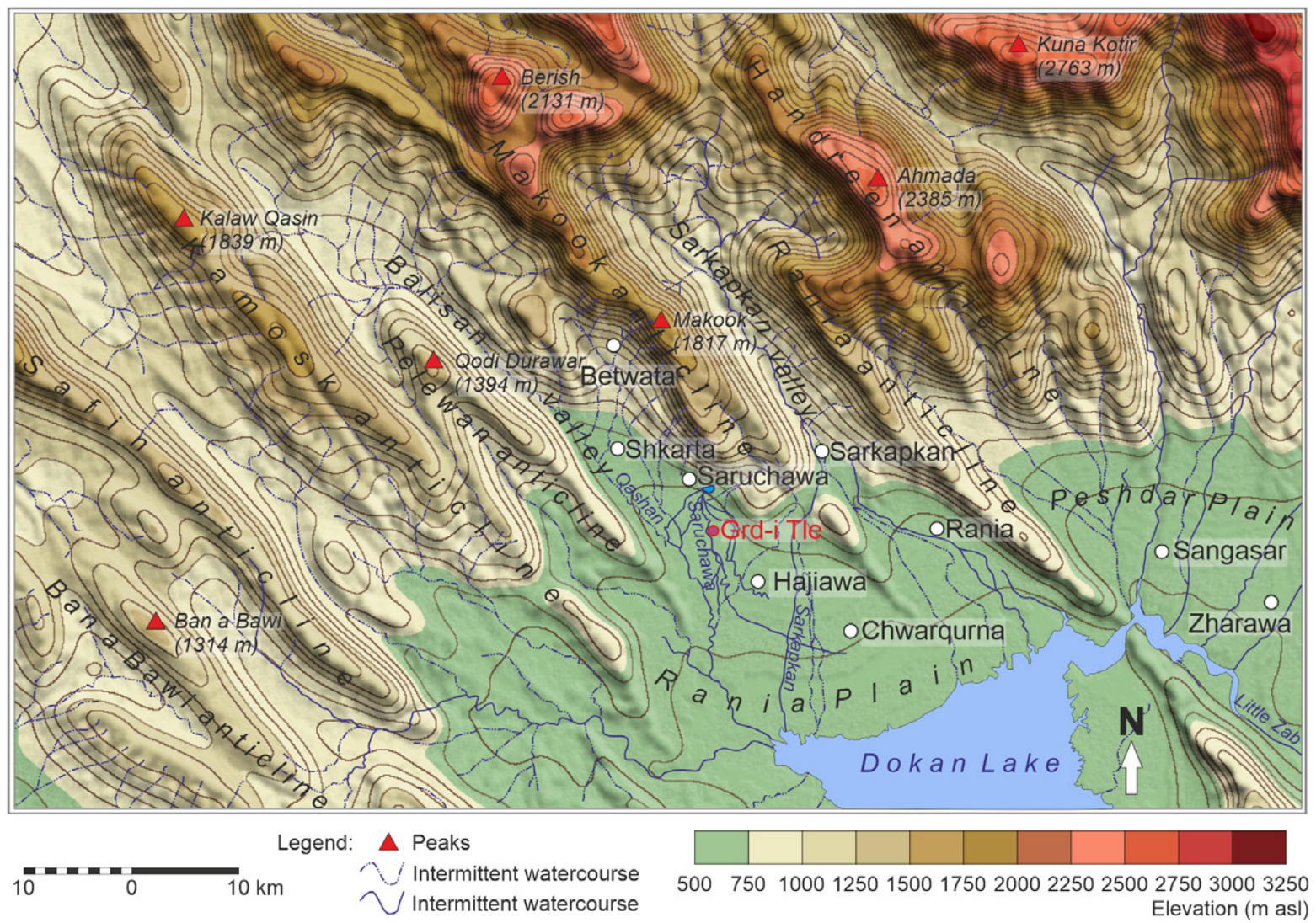

FIG. 1. Topographic map of the study area (I. Viczián). The map is based on the $90 \mathrm{~m}$ SRTM elevation data and the JOG map of Iraq, series 1501 AIR, sheet NJ 38-14, by the Defence Mapping Agency Aerospace Center, St. Louis, Missouri, 1991.

research topics. The first one reveals the geographical potentials for irrigated agriculture and the role of the abundant Saruchawa Spring. The second one examines the potential source of construction material for building this large mound.

\section{Methods}

The project involved geomorphological fieldwork: exploring, mapping and analysing landforms, revealing processes, patterns and evolution, and observing human-environmental interactions in the landscape. The morphological and lithological examination of stones from the site and its broader area was also part of the work. Soil and sediment samples were collected from archaeological profiles in the excavation area and from boreholes drilled with a hand-operated Eijkelkamp auger in the broader area. The results of the laboratory analysis of the soil's physical and chemical properties are not presented here.

The geomorphological investigations were based on data analysis from various sources: the United States' first photographic spy-satellite mission ${ }^{1}$ from corona.cast.uark.edu; modern satellite images such as Google and Yandex at satellites.pro; SRTM 90m DEM Digital Elevation Database from srtm.csi.cgiar.org; topographic maps from legacy.lib.utexas.edu and field observations. The topographic data were analysed and presented in GIS. The maps and figures were produced using the ArcGIS, Photoshop 3D map generator, SAS Planet and Corel Draw programs. 


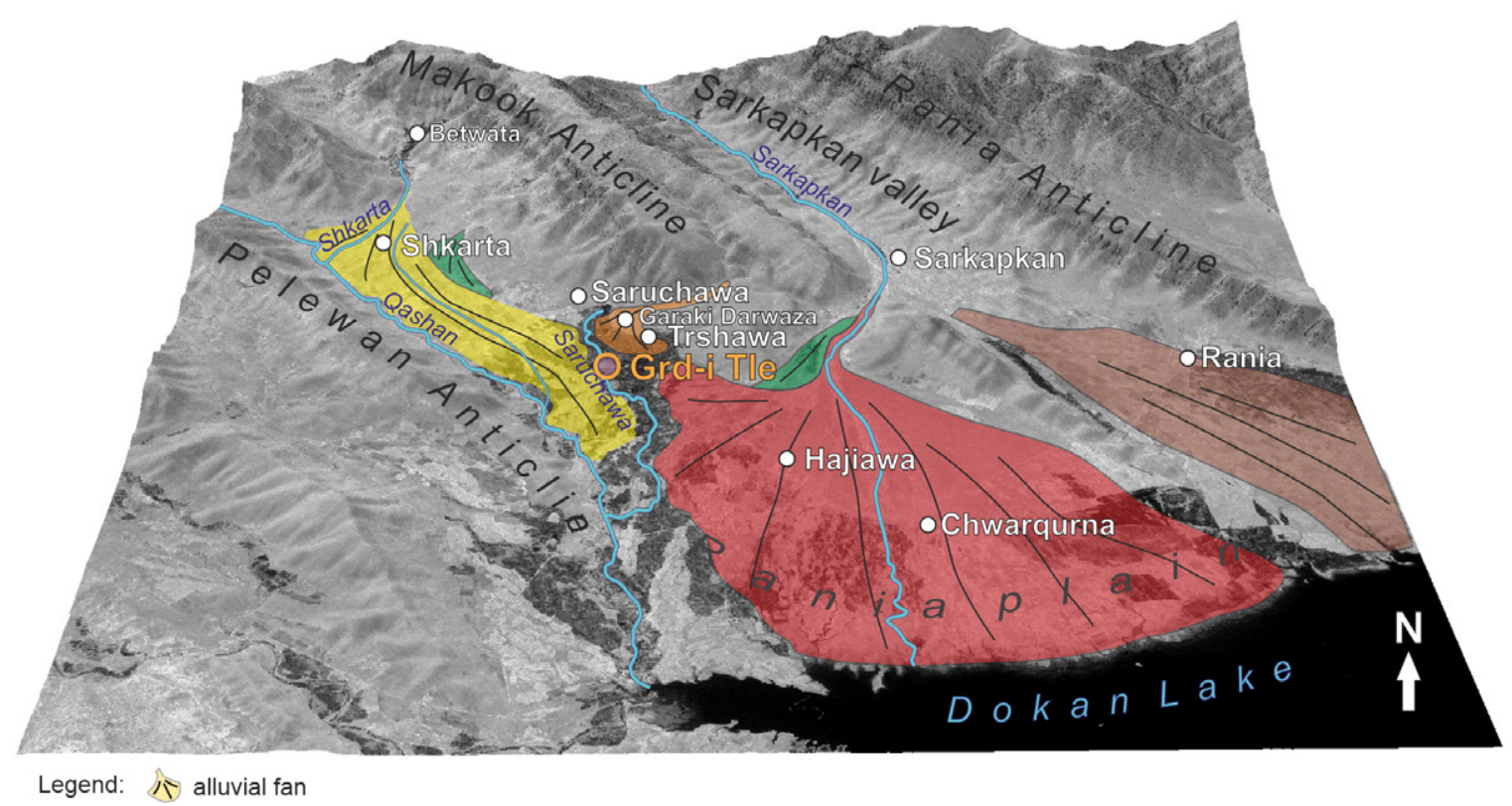

FIG. 2. Alluvial fans in the broader area of Grd-i Tle (I. Viczián). The base maps for the DEM are the CORONA 1968 spy-satellite images from corona.cast.uark.edu

\section{Location and geological context}

The Rania Plain lies within the Zagros Fold-and-Thrust Belt. This mountain range extends over $2000 \mathrm{~km}$ from Turkey to southeastern Iran and is formed mainly by the collision of the converging Arabian and Eurasian/Iranian tectonic plates since the Late Cretaceous. ${ }^{2}$

The Zagros orogenic belt consists of five tectonic zones that for the most part run parallel to one another along a northwest to southeast strike. ${ }^{3}$ The Rania Plain lies within the High Folded Zone (HFZ) between the Foothill Zone to the southwest and the High Zagros or Imbricated Zone to the southeast. The HFZ consists of three to six parallel, highly folded, massive northwest to southeast trending limestone ridges, sets of mountain ridges (anticlines) and valleys in-between (synclines). ${ }^{4}$ The Rania Plain forms a wide tectonic gap, dissecting the series of longitudinal and narrow anticlines and synclines due to a set of northeast to southwest trending normal step faults. The subsiding eastern part of the Rania Plain developed along several transversal features. The block above the fault (the hanging wall) corresponds to the Makook and the Rania anticlinal ridges, and the Sarkapkan valley in-between (Fig. 1). ${ }^{5}$ The subsiding fault block (the footwall) corresponds to the main part of the Rania Plain, whose greater part is now inundated by an artificial lake. The Lake Dokan reservoir covers an area of about 25,000 ha. The construction of the Dokan Dam on the River Little Zab between 1954 and 1959 created this reservoir. The neotectonic activity in the Rania region is consistent with the shortening across the fold-thrust belt and associated with occurrences of earthquakes. ${ }^{6}$

The Qashan Stream ${ }^{7}$ (or Rubar-i-Basalam) is a tributary of the Little Zab on the right bank. Its alluvial plain lies in the valley between the Makook and the Pelewan anticlinal ridges in the Balisan

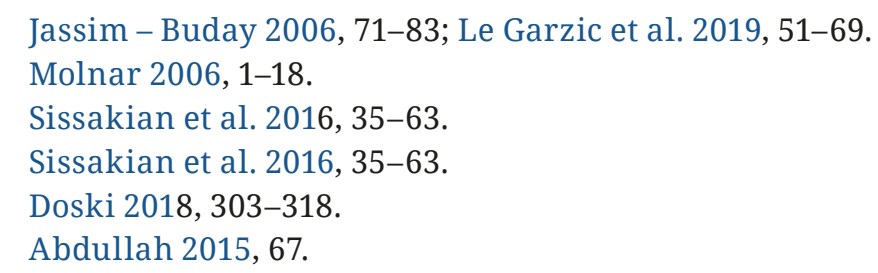



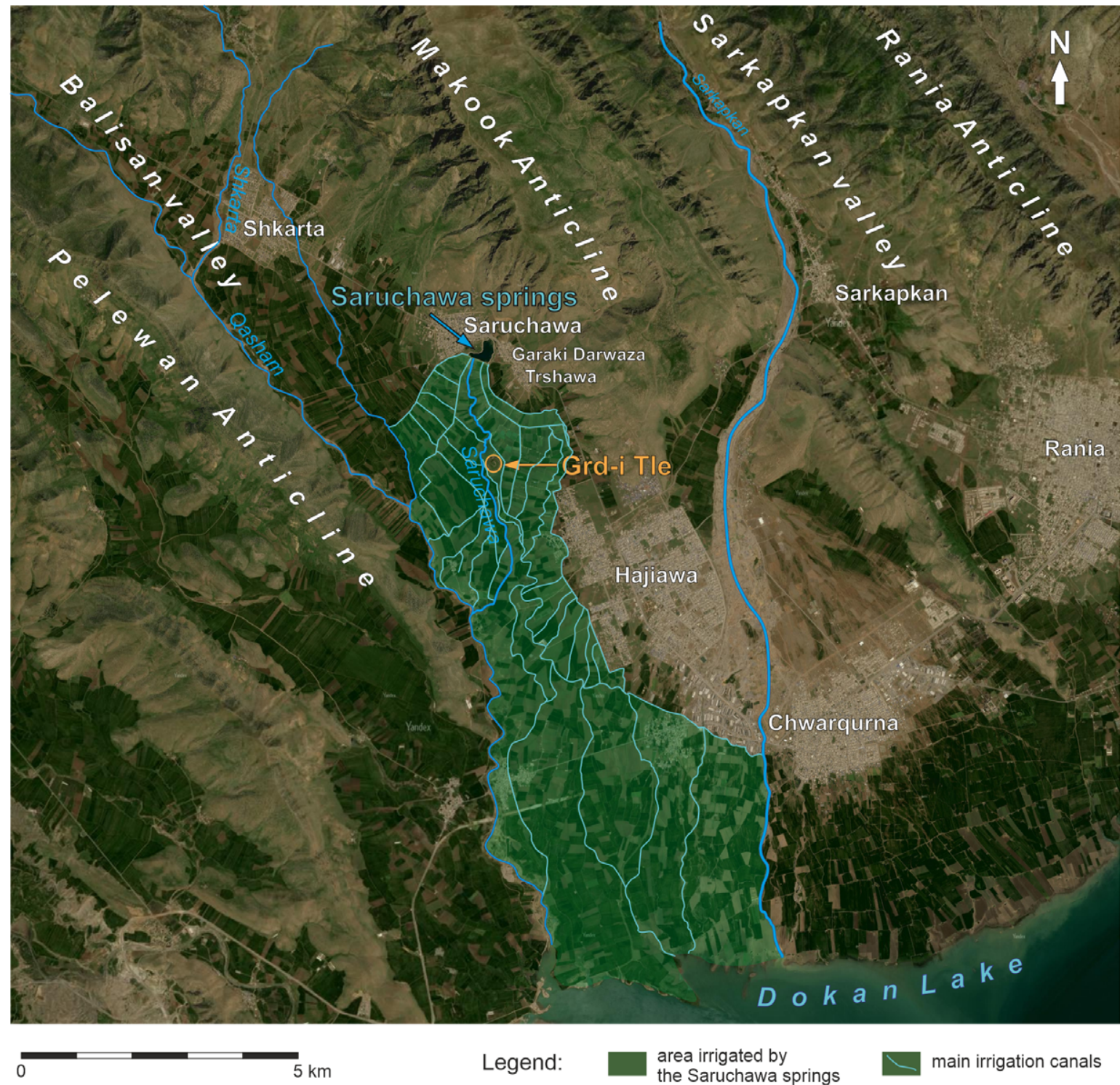

FIG. 3. Irrigated areas in the broader area of Grd-i Tle (I. Viczián). Base map: Yandex satellite imagery

synclinal valley (Figs 1-2). Its area forms a tongue of the Rania Plain extending northwestward. The stream has a terraced valley; the channel is incised in Quaternary deposits. The stream currently has long, intermittent sections. Its main tributaries take their source from abundant perennial karst springs on its left side, such as the Saruchawa, Shkarta and Betwata Springs and the springs along the Sarkapkan Stream. ${ }^{8}$

The site of Grd-i Tle is located in the western part of the Rania Plain, on the alluvial plain of the Qashan Stream near the village of Saruchawa (Fig. 1). It lies about halfway between the mountain front of Makook and the Qashan Stream, approx. two kilometres from both. The tell overlooks the Saruchawa Stream, which takes its source from a group of particularly abundant karst springs in Saruchawa. ${ }^{9}$ The springs have an estimated average annual discharge of $6514 \mathrm{l} / \mathrm{s} .{ }^{10} \mathrm{The}$ water has been used for irrigating the land for millennia. Grd-i Tle lies in the centre of the area irrigated by a fine network of irrigation canals.

\footnotetext{
8 Mustafa et al. 2015, 50-51.

9 Mustafa et al. 2015, 48-68.

10 Al-Manmi 2008, 1-225.
} 


\section{Results}

\subsection{Geomorphological context}

The fundamental landforms of the study area are the parallel mountain ridges and the alluvial plains in the basins and valleys. The Grd-i Tle site is located in the Balisan synclinal valley. The Qashan Stream is the axial watercourse of the alluvial plain. The Qashan has an asymmetric valley. The stream flows close to the mountain front of the Pelewan anticlinal ridges and has a steep north-facing slope on the right side (Fig. 2). On the left side, it has a comparatively broad and gentle south-facing terraced alluvial plain in the foreland of the Makook. The location of the river terraces indicates that the riverbed gradually shifted southward and incised into its former alluvial plain. The avulsion of the channel is controlled by the orogenic uplift of the Makook region and the Quaternary climate changes. The Qashan alluvial plain is dissected by the channels of its left side tributaries such as the Saruchawa, Shkarta and Sarkapkan Streams.

A series of alluvial fans and debris cones are lined up at the junction of the alluvial plain and the mountain front of the Makook Ridge (Fig. 2). The alluvial fans accumulate at the mouth of the high gradient, narrow mountain valleys at the base of the ridges, where the stream suddenly decreases its transporting power. The fan is composed of poorly sorted streamflow and debris flow sediments. The fan heads are rich in rock fragments, boulders, cobbles and local gravels. The fan deposit is much less coarse toward its distal margin than headward. Alluvial fans extend to the surface of the fluvial terraces and cover it partly with their sediments. Streams mark the natural boundary of the alluvial fan formation. Besides the alluvial fans, the area receives considerable amounts of slope sediments from the Makook. These sediments cover the feet of the mountain slopes and the area between the cones of the alluvial fans. Watercourses such as the Saruchawa Stream cross the belt of alluvial fans and the alluvial plain below (Fig. 2). The Saruchawa Stream developed its floodplain along the channel between the alluvial fans and within the alluvial plain of the Qashan Stream (Fig. 2). The area north of Grd-i Tle is part of the toes of the alluvial fan, while the area to its south of the alluvial plain of the Qashan Stream and its tributaries. Both the inactive distal fans and the alluvial plains are used as agricultural land. Their surfaces are stable and flat and are covered with a reddish-brown clayey soil.

The fans confined by the Saruchawa Stream are the following: the coalesced fan at the villages of Shkarta and Saruchawa in the west, the fan around the villages of Garaki Darwaza and Trshawa to the north, and the fan around Hajiawa and Chwarqurna to the southeast. These will be described in detail below.

The first alluvial fan is in the west at the mountain front of the Makook Ridge where a sequence of adjacent alluvial fans laterally coalesces to form a bajada. It is a coalesced fan of the abundant karst spring of Shkarta and other perennial, intermittent or ephemeral mountain streams and debris cones. The bajada covers the alluvial plain with sediments of gradually decreasing extent and thickness towards the Qashan Stream. The most active depositional lobe is located along the current channel of the Shkarta Stream. It flows into the Qashan, west of Shkarta (Fig. 3). Arable farming dominates the fluvial terraces and the inactive, abandoned lobes of alluvial fans. The Saruchawa lies in the mid-fan area on the right side of the Saruchawa Stream, in the northeastern angle of the coalesced fan. This alluvial fan interfingers with the alluvial fan lying north of Grd-i Tle.

The second alluvial fan is in the north, located above Trshawa. It sources in a mountain valley in the Makook Ridge, formed by intermittent and ephemeral streams. The valley and the fan-head have rough surfaces with boulders, cobbles, and other unconsolidated sediments. The 
valley provides a natural route to the mountain region for shepherds. The lower mid-fan and the distal areas are under arable cultivation. The end of the alluvial fan is marked by the Saruchawa Stream, which flows along the curve of the fans' distal west margin. The stream turns southsoutheast after Grd-i Tle, from where its channel pattern changes from a single straight and meandering channel to an anabranching multi-channel one. The stream flows between the western and eastern alluvial fans on its inter-fan alluvial plain.

The arable land on the stream's left side lies on gentle slopes: its northern section developed on debris slopes, its southern part beyond Hajiawa was formed on the abandoned fan lobe of the Sarkapkan Stream. The third alluvial fan is located east of Grd-i Tle and is one of two fans formed by the Sarkapkan Stream. Both fans are located at the fault scarp in the slopes below the mountain margins beyond the village of Sarkapkan (Fig. 2). The watercourse has a large drainage basin as it collects the waters of numerous karst springs along its valley. One alluvial fan lies in the southeastern continuation of the Sarkapkan valley around the city of Rania. The fan's lobe became abandoned here since the main course of the Sarkapkan Stream no longer flows in this area. The second larger fan developed below Sarkapkan, where the present watercourse makes an abrupt turn to the southwest and the fan spreads towards Hajiawa, Chwarqurna and Grd-i Tle. The active depositional lobe lies between Hajiawa and Chwarqurna. The settlements in both fans are located on the abandoned older fan segments in the upper part of the mid-fan zones. The arable land lies below, at the lower mid-fan section and the base of the fan.

\subsection{The irrigation system and its geomorphological context}

The Saruchawa Spring emerges at the meeting point of mountains and the alluvial plain, which is also the meeting point of the two different types of agriculture. Pastoralism has a long tradition in the mountain area and the alluvial plain consists mostly of arable land. The fields around Grd-i Tle are irrigated by the surface water of the Saruchawa Spring (Fig. 3). Springs serve as watering places for sheep as well. The Saruchawa Spring emerges at an altitude of 547-559 m a.s.l., 2-3 km away from the Qashan Stream. It takes its source $20 \mathrm{~m}$ above the local base level: the channel of the Qashan. This relative elevation difference and the topographic conditions allow for the distribution of water across large areas. The karst spring discharges water at an exceptionally high flow rate all year round. The water flows by gravity through canals, ditches and the natural channel of the Saruchawa Stream. The open-surface irrigation system has an extensive canal network; it irrigates $12 \mathrm{~km}^{2}$ of arable land and creates fishponds. This area represents about $2.5 \%$ of the total area of the Rania Plain.

The irrigated land is part of the lower mid-fan and distal fan of the surrounding alluvial fans, the attaching debris slopes and the alluvial plain of the Qashan and Saruchawa Streams. The pattern of the irrigation system aligns with the landform of the alluvial fans to a great extent. The primary canals run along the lobe curvatures of the alluvial fans in the west, north and east. The secondary canals align with the alluvial fan's radial lines. The adjacent streams mark the natural boundary of the canal system. The areas irrigated by the Saruchawa Stream are considered to have the most favourable conditions in the region in terms of arable farming, even without the spring. They are flat or have a gentle slope. Alluvial deposits are less coarse and covered with a thick layer of soil, and the groundwater table is closer to the surface than in the upper parts of the fan. Other areas of the Rania Plain, which lack an irrigation system, are also used for growing crops and fruits. These are characterized by an array of small open pits through which groundwater is accessed for irrigation purposes. This is especially common around Rania and Chwarqurna at the toe of the alluvial fans of the Sarkapkan Stream. 


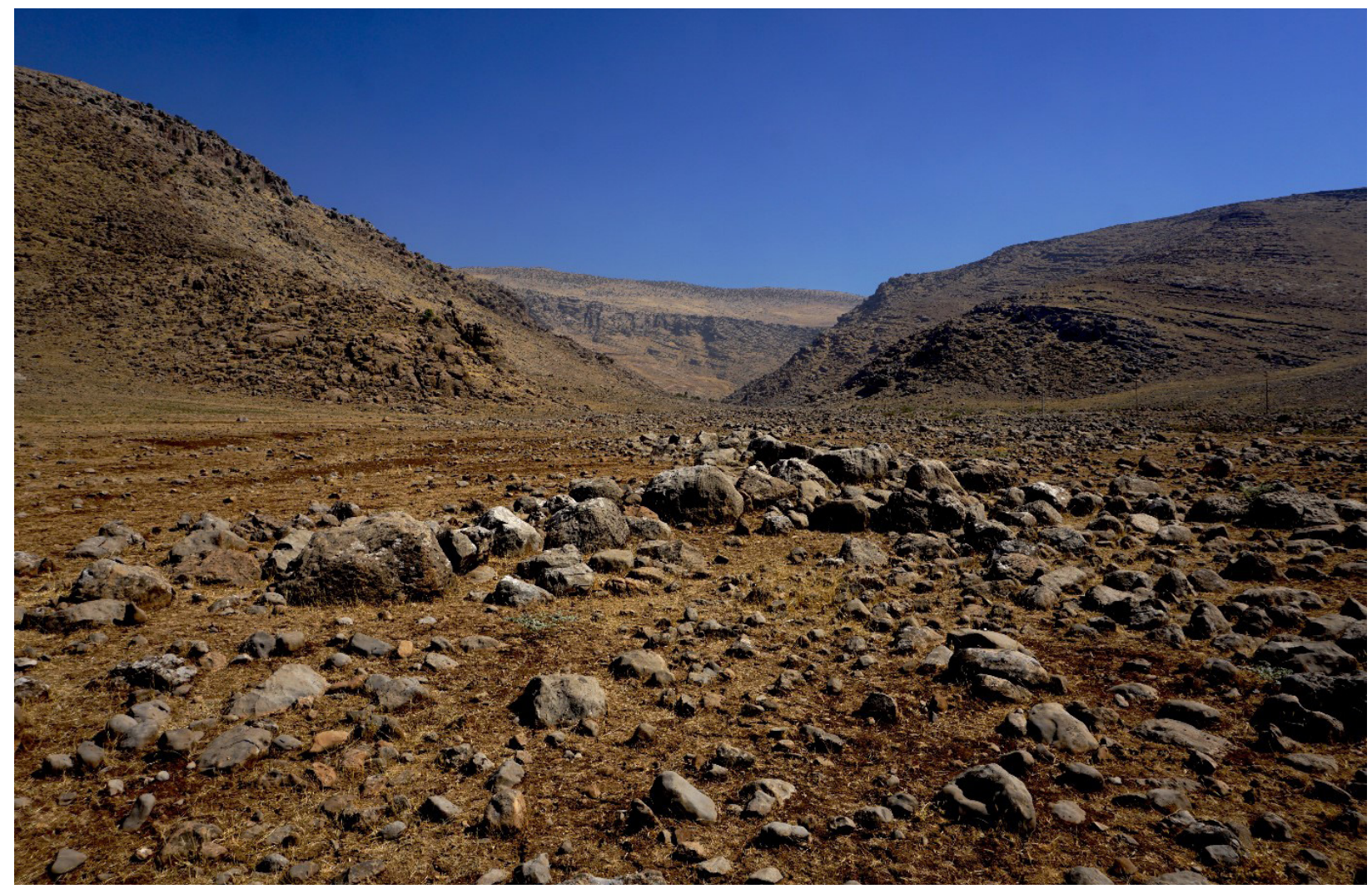

FIG. 4. Boulders and cobbles in the proximal zone of the alluvial fan in the Garaki Darwaza-Trshawa area, 1-3 km northeast of the tell (Photo: I. Viczián).

\subsection{Potential source of Grd-i Tle's construction materials}

Grd-i Tle lies on the left bank of the stream and rises above the surrounding plain by $26-28 \mathrm{~m}$. The original relative height was presumably over $30 \mathrm{~m}$. The present, eroded plateau of the tell lies $30 \mathrm{~m}$ higher than the top of the canal excavated in the outer city. The remains of a well-built stone embankment built on top of a previous city wall were identified at the foot of the tell along the stream. The tell is an artificial mound built up by some $1,716,496 \mathrm{~m}^{3}$ of material, calculated from the 3D GIS analysis of drone-captured images. This magnitude demonstrates the importance of the tell, as this high ground in the middle of the plain was an ideal location for observing enemy movements and actions, and for controlling the area. The analysis of the CORONA spy-satellite images from the 1960s and field observations revealed that there was a network of tells in the vicinity of the investigated tell. Grd-i Tle was undoubtedly the most important among them, both in terms of its size and significance. ${ }^{11}$

The tell mainly accumulated from the remains of degraded mudbricks and the stone remains of foundations and walls. Raw materials used in construction were available from nearby sources in considerable quantities. Water, clayey soil, or fine alluvial sediments used for mud-brick manufacturing can be found at the waterfronts near the tell, while organic ingredients such as straw or other fibres would have been readily accessible from the nearby fields.

The stones found on the site have been predominantly identified as the hard carbonate rocks of the Bekhme and the Kometan formations. A large proportion of the building stones on the tell are unworked or nearly unworked; their shape and material resemble the boulders, cobbles and

11 Kalla - Dezső 2019, 1-12. 
pebbles $^{12}$ found on the alluvial fan in the Garaki Darwaza-Trshawa area northeast of the tell (Fig. 4). The fan's proximal zone and backfilled mountain front embayment lying 1-3 kilometres from the site are rich in coarse gravelly sediments. The building stones most probably originated from the upper part of this fan. The stones used for construction did not have to be mined from open quarries; it was sufficient to collect stones of the appropriate size and material from the surface. Aside from this source, the solid rocks of thick-bedded limestone at the mountain front next to the fan are also suitable for extracting stone as building material in an open-pit mine. It should be noted that no surface features indicating significant quarrying activity can be observed in the broader area. It is still common practice to use the material of alluvial fan deposits for construction purposes. The active depositional lobe of the Hajiawa-Chwarqurna alluvial fan in particular is heavily quarried today.

\section{Conclusion}

Grd-i Tle is located in the Balisan synclinal valley between the Makook and the Pelewan anticlinal ridges on the terraced alluvial plain of the Qashan Stream. It lies at the meeting point of the mountains, where pastoral farming prevails, and the alluvial plains, where arable farming predominates. The nearby Saruchawa springs provide an exceptionally abundant supply water for both domestic and irrigation needs all year around, a very precious feature in a semi-arid continental area.

The tell lies on the left bank of the Saruchawa Stream, surrounded by alluvial fans. The Saruchawa Spring emerges at a mid-fan area, $20 \mathrm{~m}$ above the local base level of the Qashan Stream. The main irrigation canals run along the contour line of the alluvial fan cones and network the fertile lower part of the fans and the alluvial plains. These areas are covered with well-developed soil. Subsurface waters are stored near the ground in large aquifers, also accessible for agriculture.

The tell is predominantly made up of degraded mudbricks and blocks of stones. The morphological and lithological analysis of the stones from the tell and its broader area indicates that the construction material was collected from the boulders of the nearby fan-head area of the alluvial fan around Garaki Darwaza and Trshawa, two kilometres to the north. Raw materials used for mud-brick production were available on the floodplain of the Saruchawa Stream surrounding Grd-i Tle.

The geographical features around Grd-i Tle are unique and most favourable for human settlement on the entire Rania Plain and it is therefore hardly surprising that the place has been repeatedly or continuously occupied since the Neolithic.

\section{Bibliography}

Aвdullah, H. Sн. 2015: Water quality assessment for Dokan lake using Landsat 8 OLI satellite images. Unpublished MSc Thesis (University of Sulaimani). Sulaimani. https://doi.org/10.13140/ RG.2.2.11499.03360

AL-Manmi, D. 2008: Water Resources Management in Rania Area, Sulaimaniyah NE-Iraq. Unpublished PhD Thesis (University of Baghdad). Baghdad.

12 Kalla - Dezső 2019, 1-12. 
CORONA 1960-1972: https://corona.cast.uark.edu/ - Center for Advanced Spatial Technologies, University of Arkansas/U.S. Geological Survey.

DosкI, J. A. H. 2018: Tectonic interpretation of the Raniya earthquake, Kurdistan, northern Iraq. Journal of Seismology 23, 303-318. https://doi.org/10.1007/s10950-018-9807-0

Jassim, S. Z. - Buday, T. 2006: Tectonic Framework. In: Jassim, S. Z. - Goff, J. C. (eds.): Geology of Iraq. Brno, 71-83.

Kalla, G. - Dezső, T. 2019: Hungarian Archaeological Expedition in the Mountains of Iraqi Kurdistan. Excavations Undertaken by the Faculty of Humanities, Eötvös Loránd University, at Grdi Tle (Rania Plain). Hungarian Archaeology 8/4, 1-12. https://doi.org/10.36338/ha.2019.4.4

Le Garzic, E. L. - Vergés, J. - Sapin, F. - Saura, E. - Meresse, F. - Ringenbach, J. C. 2019: Evolution of the NW Zagros Fold-and-Thrust Belt in Kurdistan Region of Iraq from balanced and restored crustal-scale sections and forward modelling. Journal of Structural Geology 124, 51-69. https://doi.org/10.1016/j.jsg.2019.04.006

Molnar, M. 2006: Tertiary development of the Zagros Mountains. Geol 418-Earth History. https:// people.uwec.edu/jolhm/Student_Research/Molnar/reports/zagros.pdf

Mustafa, O. - Merkel, B. - Weise, S. M. 2015: Assessment of hydrogeochemistry and environmental isotopes in karst springs of Makook anticline, Kurdistan Region, Iraq. Hydrology 2, 48-68. https://doi.org/10.3390/hydrology2020048

Sissakian, V. K. - Abdul Ahad, A. D. - Al-Ansari, N. - Hassan, R. - Knutsson, S. 2016: The regional geology of Dokan area, NE Iraq. Journal of Earth Sciences and Geotechnical Engineering 6, 35-63. 
奉 HAR

HUNGARIAN ASSYRIOLOGICAL REVIEW

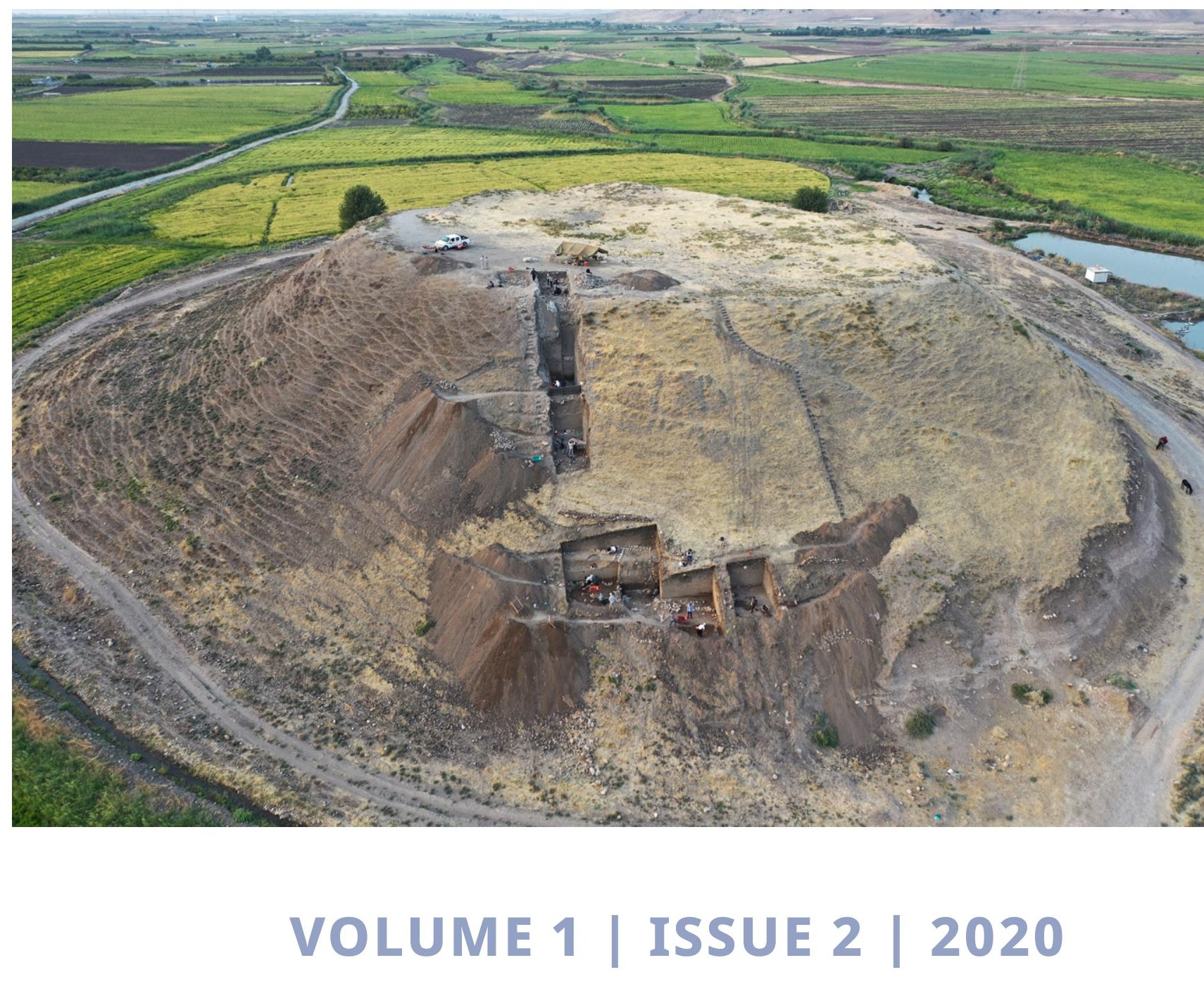





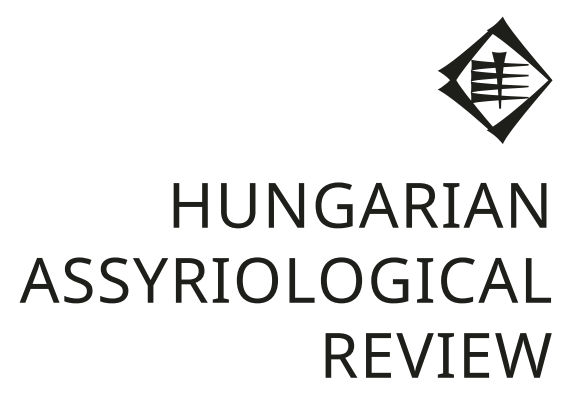


ON THE COVER:

Excavations at Grd-i Tle in 2019 -

the northern face of the tell with Trenches I and IV.

Photo: ELTE Archaeological Mission in Iraqi Kurdistan. 


\section{HUNGARIAN ASSYRIOLOGICAL REVIEW}

\section{VOLUME 1, ISSUE 2 2020}

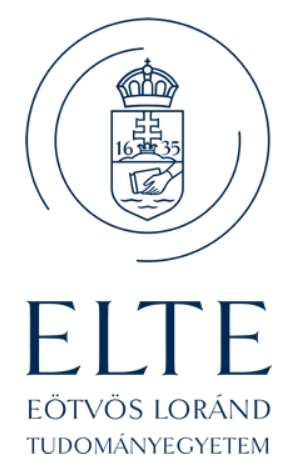

Institute of Archaeological Sciences

Institute of Ancient and Classical Studies

Eötvös Loránd University

Budapest 


\section{HUNGARIAN}

\section{HAR - Hungarian Assyriological Review}

Journal of the Institute of Archaeological Sciences and the Institute of Ancient and Classical Studies (Department of Assyriology and Hebrew Studies), Eötvös Loránd University, Budapest, Hungary.

HAR is a peer-reviewed electronic journal (HU ISSN 2732-2610) published in two issues per year. The journal covers the philology and the archaeology of the Ancient Near East, publishing research articles, brief notes, and field reports.

Papers in HAR are published under the platinum open access model, which means permanent and free access in downloadable format ( $p d f$ ) for readers and no publication fees for authors. The issues can be both downloaded for free and ordered as printed volumes at own cost.

For article submission guidelines, see https://harjournal.com/author-guidelines/

\section{Editorial board}

Editor-in-chief (szerkesztésért felelős személy):

Gábor Kalla, Eötvös Loránd University, Budapest

Associate editors:

Zsombor J. Földi, Ludwig-Maximilians-Universität, München

Zsolt Simon, Ludwig-Maximilians-Universität, München

\section{Editorial board:}

Tamás Dezső, Eötvös Loránd University, Budapest

Gábor Zólyomi, Eötvös Loránd University, Budapest

Technical editor:

Attila Király

Publisher (kiadó és kiadásért felelős személy):

Gábor Kalla, Eötvös Loránd University, Budapest

Registered office (a kiadó székhelye):

Institute of Archaeological Sciences, Múzeum krt. 4/B., 1088 Budapest, Hungary

\section{Email address:}

info@harjournal.com

\section{Design and typesetting:}

Attila Király (attila@litikum.hu)

using Noto font family by Google Inc., under the terms of the SIL Open Font License. 


\section{CONTENTS}

\section{Hungarian Assyriological Review}

\section{volume 1, issue 2,2020}

Early Babylonian tablets in the British Museum's Kuyunjik Collection 1:

A fragment of an administrative document from Ur III Girsu?

Zsombor J. Földi

The morphophonological analysis of Hittite šipantaš, šipandaš '(s)he libated'

Alwin Kloekhorst

A fresh look at recently published Anatolian hieroglyphic seals

Massimo Poetto

Floh im Ohr: Forrers Ahhijawā-Deutung, Āhhijā und ihr kilikischer Nachzügler Hijawa

Diether Schürr

\section{Hungarian Excavations at Grd-i Tle}

The geomorphological and environmental context of the Grd-i Tle archaeological site István Viczián

Hungarian Assyriological Review author guidelines 